\title{
Youth Unemployment in Emerging Economies:
}

\author{
Is There Role for Macroeconomic Policy? New Evidence in the Case of Indonesia
}

\author{
Eva Lathifah Ali* \\ Education, Public Policy \& Equity, School of Education \\ University of Glasgow \\ Glasgow, UK \\ *evalathifah6@gmail.com
}

\begin{abstract}
The 1997 Asian financial crisis and the recent global financial crisis affect labour market outcomes significantly, particularly for emerging economies such as Indonesia. However, twenty years after the crisis, with economic recovery on its way, job crisis on the vulnerable groups of the labour market has not yet fully recovered, especially young people. The occurrence of this issue is also inextricably related to other critical concerns in social well-being and economic problems, and it is for this rationale that the analysis of youth unemployment, and the development of relevant policies to generate productive employment, is of great importance. In regard to this, Government of Indonesia seems to be focus to a structural and supply-side view of youth unemployment derived from lack of appropriate skills as well as "wage-push" orthodoxy. There has indeed been much work done on tackling youth unemployment issue from supply-side perspective. However, there is a lot still to be gained with respect to demand-side approach by taking macroeconomic analysis on youth labour market outcome, and it is from this angle that $I$ aim to contribute to the Indonesian youth unemployment debate. This research will attempt to develop an alternative way to understand the youth unemployment issue in Indonesia, one that considers the current labour situation as the reflection of a demand-constrained economy. Using a Keynesian account in which aggregate demand holds back output and employment growth, this research hopes to develop a more analytically persuasive understanding of the drivers of poor youth employment outcome and that proposes an alternative framework in the macroeconomic policy within the Post Keynesian approach. Such analysis will enable governments to understand the extent to which changes in the macroeconomic policy environment can improve job creation and employment outcomes for young people.
\end{abstract}

Keywords-job creation, macroeconomic analysis, youth unemployment

\section{INTRODUCTION}

The need to reduce youth unemployment and build employment pathways for young people have become concern and increasingly discussed among Indonesian policy makers. Based on Statistics Indonesia (BPS), youth unemployment rates are more than twice higher than the adult rates, with an increase after the 1997 Asian Financial Crisis (AFC) [1]. The crisis has indeed had immense consequences on labour productivity, employment and economic performance as a whole. Twenty years after the crisis however, with economic recovery on its way, one noteworthy effect such as job crisis on the vulnerable groups of the labour market has not yet fully recovered, especially young people [2]. This phenomenon has led to an increasing debate over the causes and the consequent interventions to this urgent issue. Moreover, the occurrence of this problem is inextricably related to other critical concerns such as inequality, poverty, crime and general social well-being and economic problems. What is less-discussed is the long-run scarring-effect that youth can suffer for the later stages of working life if they have a difficult transition to the labour market [3-5]. Moreover, high youth unemployment is also linked to mental health issue and higher incidence of crime and drug offences [6]. Joblessness effects young people's lives in the most fundamental way, and it is for this rationale that the analysis of youth unemployment, and the development of relevant policies to generate productive employment, is of great importance. In addition, Indonesia is also anticipating a big harvest of its demographic bonus and will be dominated by its huge working age group that in 2030, expected to reach 70 percent of the total population [7].

In regard to this, Government of Indonesia seems to be focus to a structural and supply-side approach of youth unemployment derived from lack of relevant skills as well as "wage-push" orthodoxy [8]. Investigating skills and educational attainment as the drivers on poor youth employment outcomes has been the most frequently used analysis by policymakers, including the International aid agencies as they are considered to be 'treatable' by relevant policy designs [9]. Hence, extending the access to vocational education is often the chosen policy that Government takes in order to raise youth employment, and this is especially the case for Indonesia. Another influential argument in Indonesian youth unemployment debate is insufficient labour market flexibility which believes that the "wage-push" orthodoxy is the reason behind job crisis faced by youth population.

This issue of structural and supply-side approach forms the basis for much of the debate surrounding youth unemployment problem in Indonesia. While increasing productivity by 
focusing on supply-side investments in skills and training might look appealing, there are risks entangled in any policy designs that simply targets at raising the supply of skilled workers, without a comprehensive analysis of the economy [10]. As this phenomenon will confirm Indonesia as a labour surplus country, due to a shortfall in employment opportunities as the economic growth is slower than the growing size of new entrance in the labour force [11]. In emerging countries, therefore, future success is largely relied on their capability to generate productive working opportunities [12]. In practice, this requires a fundamental study of macroeconomic policies, and the outcomes that it produces in order to identify challenges to Indonesian youth labour market. There has indeed been much work done on tackling youth unemployment issue from supply-side perspective making the policy debate around unemployment more informed. However, there is a lot still to be gained with respect to demand-side approach by taking macroeconomic analysis on youth labour market outcome, and it is from this angle that I aim to contribute to the Indonesian youth unemployment debate.

This paper will attempt to develop an alternative way to understand the youth unemployment issue in Indonesia, one that considers the current labour situation as the reflection of a demand-constrained economy [8]. All the key macroeconomic indicators - investments, imports and consumption-point in that direction. Using a Keynesian account in which a shortfall in demand for labour holds back output and employment growth, this dissertation hopes to develop a more analytically persuasive understanding of the drivers of poor youth employment outcome than the narrative offered by the advocates of structural and supply-side practices, and that proposes an alternative framework for macroeconomic policy within the Post Keynesian narrative. Such analysis will enable governments to understand how changes on the macroeconomic policy environment can generate job opportunities for the youth population. In addition, studies of financial crisis in Indonesia are relevant for their repetitive nature and their serious impacts on the economic environment.

This study is designed to address the following key questions:

- How a significant growth of youth unemployment in Indonesia after the Asian 1997 crisis can be explained? What are the debates over the causes and consequent solutions toward it?

- What macroeconomic and labour policy course did Indonesian government take to solve the growing youth unemployment rate since the crisis? What are some of the challenges?

- What are some policy implications that emerged from the analysis of macroeconomic environment of growth and youth unemployment problem in Indonesia?

In order to answer the research questions above, both qualitative and quantitative methods are going to be used equally. As they encompass the theoretical and factual data for the final discussion of this study, both techniques are important to this research.

As this paper is going to analyses key macroeconomic indicators reflected in the economic statistics document of Indonesia, I have to be aware of the major economic downturn events experienced by the country. The 1997 Asian Financial Crisis (AFC) and Global financial crisis are commonly discussed by policymakers, however the recent COVID-19 outbreak is also one significant phenomenon that government simply cannot ignore. Due to the availability of data and literature sources in which this research depends, I will primarily focus on analysing the economic environment after the AFC while also highlighting some of the prominent effects of global financial crisis. As the writing of this dissertation started at the beginning of the recent COVID- 19 pandemic which in Indonesia the first imported case was reported in early March, data presented were also collected and analysed before this outbreak. The pandemic, on the other hand, have indeed affected the economic situation substantially in term of key macroeconomic indicators (GDP, private and public consumption, investment) as well as employment productivity. However, in order to have a well-grounded analysis and to capture the complexity of the impact of major crises on youth labour market outcome in a long run, it may be too early to do investigation even for short-term effect of COVID-19 as the pandemic is still ongoing and the impact it brings still yet accumulated. Therefore, how this outbreak affected economy as a whole shall needs further analysis for the future research. Furthermore, since this study puts forward macroeconomic indicators including fiscal and monetary policies, the intention of this paper is neither to address all the relevant details of each indicators nor to conduct econometric statistics approach, but to analyses the coordination of these policies and the effects they bring for youth labour market productivity.

\section{THEORETICAL FRAMEWORK}

\section{A. Macroeconomic Models: Overview}

In most countries, macroeconomic models have been commonly applied to formulate policy design in the economic sector. These models are largely used not only to analyses the demand and supply side and the whole resource allocation process but also to reduce fluctuations which will enhance the economic growth. To analyses fluctuations of output, price level as well as employment, two major economic approaches have evolved over time namely, Classical and Keynesian [1317]. In regard to Classical models, real wages played a major role to make demand for labour and its supply in a balance condition, determined level of output as well as level of employment. Unemployment cannot occur in this classical system simply because the price is flexible in which the demand for labour always equals its supply.

The role of government in this model is limited to lawrelated decision to ensure the development of business enterprises. Apart from that, less government intervention is recognized in this system and considered better. As the 
economic growth developed rapidly throughout the nineteenth century, although with few disruptions, this Classical system have been promoted and influenced policymakers from the time of Adam Smith in 1776 up to Marshall or Pigou in 1920s. However, the notion that aggregate demand always equals aggregate supply did not applicable and was not in line with the incidence emerged in late 1920s. Industries were unable to sell their excessive products which resulted in the increasing laid off employees. This further decreased the demand for labour and production capacity used below the optimal level. This phenomenon led to both social and economic problems as more than a quarter of labour force lost their jobs and became unemployed. This marked the beginning of the Keynesian macroeconomic model. Keynes showed that less intervention from the government may keep a shortfall in demand on for a long run as Keynes argue that wages are slower to respond to the needs of market therefore government intervention is needed to stay on track. The aggregate demand should equal aggregate supply in macroeconomic indicators such as investment, consumption, net exports as well as government expenditure. The behavioural assumption behind those macroeconomic indicators provide a relevant framework to analyses how fiscal, monetary and exchange rate policies effect the output, investment climate and employment [18]. When real constraints are known then this framework can be applied in the formulation of policy. In this regard, government have control over macroeconomic policy designs such as exchange rate and tax rate. This analysis would be helpful for policymaker to have a systemic framework on how the output, employment and trade balances change when policy measures are carried out. In the General Theory of Employment, Interest and Money, Keynes put forward an agenda to address one urgent issue that the major faults in the economic society are its inability to offer full employment and distribute wealth and income equally [19]. The main idea of his proposal was that the economic system should not left to the free market, and that government should have control over it to ensure the stability of monetary production economies. In addition, the instability of employment and output are associated with the entrepreneurs' decision to expand investment in which will resulted in the changes of income distribution. Therefore, it is important to ensure that economic policy support the development private sectors' investment to generate employment opportunities. In this regard, macroeconomic policies (fiscal, monetary and exchange rate) played a significant role to keep the stability of entrepreneurs' investment climate.

\section{B. Why Are Macroeconomic Policies Important: A Keynesian Context}

In the idea of Keynes' monetary theory of production, money is the foundation of the production process and also the desired result of the process [19]. This is what entrepreneurs invest for, to obtain more money at some future point. This investment then will improve production, generate employment and income not only to the employed but also other indirect groups who supply inputs and other aspects in the production process. It is imperative therefore to keep the production capacity utilised maximally as the economic system is demanded-led, and investment played a crucial role in it.

However, it is hard to predict whether entrepreneurs' expectation to obtain high sale from their investment is achieved. Although there are some prediction tools and methods that have been developed, the future oftentimes cannot be foretold. In this scenario, entrepreneurs rely their decision-making on expectations. This situation led to an increasing demand for money rather than capital goods which generate a demand constrained-economy and therefore affect employment and production capacity. This therefore will further increase in unemployment and decrease in income and culminate in crisis and recession. To keep the economy away from this scenario, Keynes argued that the involvement of government holds the central control to ensure full employment [19]. The primary component of the function of government lies in its macroeconomic policies to direct economic activity in a stable and business-friendly condition to do investment for private sectors. Furthermore, fiscal policy in macroeconomic model will directly influence aggregate demand for labour. Macroeconomic policies, together with other political and juridical function of the government, provide systemic institutional framework for society. The more businessfriendly, transparent and stable the economy is, the more it would stimulate investment.

\section{Methodology}

This paper is secondary research in nature, whereby already existing data is analysed. In regard to macroeconomic variables and statistics presented in this paper, two main data sources were utilised: The World Development Indicators (WDI) and the Indonesian Statistics (BPS). The World Development Indicators is primarily used for macroeconomic performance indicators such as growth, investment and consumption for Indonesia. It is a time series dataset ranging from 1990 to 2018 compiled from international and national statistics divisions. Statistics Indonesia used to explain the situation of youth unemployment in Indonesia in general. Inconsistency is to be expected in using such diverse data sources, but the underlying trends exhibit similar pattern though values may vary. In order to answer the research questions outlined in the introduction, both qualitative and quantitative methods are going to be equally applied. As they encompass the theoretical and factual data for the final discussion of this dissertation, both techniques are important to this research.

\section{DiscusSION}

Previous chapters have taken us through some of the theoretical and policy debate surrounding youth unemployment in the economy of Indonesia. We have established that the high rate of youth unemployment as one of the results of the financial 1997 crisis is indeed a significant phenomenon and that generating productive work opportunities in labour demand is very important in this regard. In this section, I will undertake a detailed macroeconomic analysis of youth labour 
market, and the constraints placed on youth in transition toward it. First, I will begin with a critical assessment of the ongoing structural supply-side view of youth unemployment based on orthodox wage-push view and skill mismatches followed by an assessment of post- crisis macroeconomic changes and policy stance in Indonesia. This chapter also presents an alternative framework in the macroeconomic policy within the Post Keynesian approach for Indonesia's employment and growth problems. A summary of the findings and drawing together of different ideas within the various chapters is then made to conclude the study.

\section{A. Debate Over Determinants of Poor Youth Employment Outcomes in Indonesia: Issues and Evidence}

There is an ongoing debate about the causes of poor youth employment outcomes which focus on the disastrous impacts of recent and contemporary macroeconomic events. Beyond cyclical fluctuations, are youth confronting difficult to integrate into the labour market due structural and supply-side aspects stemming from skill mismatches? Or is it because of institutional barriers and labour market rigidities that make youth difficult to access jobs, particularly in formal employment? Or are they mainly due to a shortfall in demand derived from the pattern of economic growth?

As explained earlier that describing the outcomes of youth labour market by educational attainment and skills has been the most frequently used approach by policymakers and analysts, including the international aid agencies as they are considered to be 'treatable' by relevant policy designs [9]. So, it is with labour market flexibility, it seems straightforward, but not always easy in practice to change laws or regulations due to complex bureaucracy system. What is much more elusive to government and policymakers is how to create productive employment opportunities for youth to ensure that human resources are not left under-utilised. The analysis in this section outlines different evidence to youth labour market analysis and put forward the argument that explanation on high youth unemployment rate lies in a shortfall in aggregate demand caused by the pattern of growth in macroeconomic policy indicators.

\section{B. Skills Deficit and Mismatch}

Are young people not skilled enough to get a job when there are vacancies available? Such question may seem almost useless in the medium to long term as many countries in the world now, prepare their younger generation with a longer period of schooling, and young participants are seen to be sufficiently skilled than ever before. However, in reality young entrants are oftentimes facing difficulties to find work even when they fairly qualified. This has been increasingly discussed and the focus tends to point on the gaps between the type of skills they obtained in schools and skills needed in the market. Consequently, matching the skills to labour market demand has always been the pressure that government put to training and vocational education providers. But implementing curricular adjustments to such short period fluctuation costs relatively high and quite complex for developing country like Indonesia as labour market information is often not reliable [20]. Balance between labour skills framework and institutional ones would indeed be required to cope with cyclical fluctuations. The ILO develops a skills framework in regard to this issue of matching skills to demand which include the coordination for all relevant actors to consistently match skills to the needs of labour market [21]. Nevertheless, despite the ongoing debates, Government of Indonesia is still enthusiastically prioritising secondary vocational education as one of the key contributors in addressing unemployment and increase economic growth. Although in reality, job recruitment practices are still far from favouring vocational schools graduates as often times, in most cases they refer as low-skill and repetitive jobs [22]. In addition, even after trying to close skills gap through vocational education, evidence from recent official statistics of Indonesia showed that unemployment rate among secondary vocational school graduates is $8.49 \%$, the highest across all education levels even in a stable condition of economic of the country [1]. Furthermore, results from an examination of the relationship between youth educational accomplishment and labour market outcomes show that high income countries have a straightforward outcome while low and middle income countries show much more complex result [23]. There are clear positive returns in high income countries where longer average years of schooling linked to lower youth unemployment rates and higher employment ratios. However, results showed differently in low and middle income countries where higher youth unemployment rates were associated with longer years of schooling. This relationship partly captures the fact that in low and middle income countries, youth unemployed are relatively better educated than their working counterparts. In Indonesia, based on Statistics Indonesia (BPS) shows that indeed many secondary vocational school and university graduates are unemployed and contributes higher rates to youth unemployment [1]. This tendency is capturing two aspects, first, the longer average years of schooling shows that many young people remain in education and out of the labour force and second, there may not be sufficient amount of demand which lead to an over-supply of educated youth. Young people from low socio-economic background are worth-noted in this incidence as they can neither stay longer in education nor able to remain unemployed in the absence of extensive unemployment benefits. This in turn has an essential implication for the "skill mismatches" view as a way to explain high rate of youth unemployment which suggests that business cycle and labour demand environment influence the relationship between skills and youth unemployment. In other words, economic downturns will lead to deleterious change in this relationship and generate low quality employment and income opportunities for youth as they will remain unemployed even when sufficiently skilled if there are no vacancies. Hence, associating poor youth employment outcome to skill deficit approach alone will be inappropriate as it will neglect the significant role of business cycle in affecting the employment prospects for youth. This does not mean that the on-going policy effort of Indonesian government in preparing better skilled workforce was not worth- invested, however, some 
measures to stimulate the job creation in the labour market would be needed to complement the policy design in the supply side.

\section{Insufficient Labour Market Flexibility}

Another influential view on youth unemployment debate is related to labour legislations. This approach argues that "wagepush" is the key to appropriate policy interventions in labour market outcomes. The notion that institutional rigidities hinder a business-friendly labour market to generate employment opportunities and growth hold true in this orthodoxy view [8]. High minimum wages and high severance pay set the roles of the game in this approach. A study that draws on a new IMF database about Middle East and African region labour market which both are among the highest youth unemployment rate in the world shows that rigid labour market regulations as commonly suggested by policymakers in the region were not the key answer to their persistent poor youth labour market outcomes [24]. The crucial message from that cross-country study shows that the appropriate policy intervention to labour market is not necessarily more or less regulation, but a relevant mix of policies that enable young workers to get sufficient benefits in terms of protection from the risks they may be facing while maintaining jobs.

Turning to Indonesia, a sharp increase in minimum wages as well as high severance pay seen even before the 1997 AFC, particularly in manufacturing sector. Some studies stated that a significant rise in minimum wages after the AFC have simply failed to decrease poverty rate in Indonesia [8]. They also argue that small domestic firms as well as formal sector employment have severely affected by the minimum wage policy and that only worsen poverty issue in Indonesia. However, the argument that one is going through a "wages boom" in the sector of manufacture depends largely on how the evidence is collected and analysed. Moreover, recent literatures were unable to identify statistically strong evidence that hiring decisions have been influenced by minimum wages in the manufacturing firms [25]. Hence, unlike the popular assumption, the manufacturing firm does not actually endure the risks from increasing labour cost as the share of labour cost as stated in the statistics report, remained constant at 7 percent since 1985 [8]. In addition, evidence from ADB study explained that there are other factors that hinder the employment growth in formal sector which in fact, are more crucial namely, macroeconomic instability, tax rates, policy uncertainty and that labour regulations cannot be the only factors in poor labour market outcomes [26]. This explanation is consistent with findings in the relevant literature such as a study by the ILO and IILS that explains a non- linear relationship between labour legislations and youth employment in which both excessive and too rigid regulations caused youth high unemployment rate [23]. The supply-side approach of the Indonesian youth labour market also often fail to explain the practical idea behind labour market flexibility and put it into policy designs that generate productive working opportunities. How low can government urge real wages in an economy where about 40 percent of the population is vulnerable to at least a temporary episode of poverty, risking the rights of worker in order to raise domestic and foreign investment? Should one demolish rigidity in the labour market while maintaining institutional rigidity that dominated by conglomerates in the corporate sector? An intense policy debate would need to also discuss these complex issues. In addition, cross-country study for the period 1980-2005 by Aleksynska and Schindler [24] outlines that poor youth employment outcomes are only insignificantly associated with level of minimum wages for both high and low and middle income countries. Hence, those evidence mentioned above mean that labour market legislations are unlikely to have a critical role on youth labour market outcomes, at least in the long term. Moreover, regulatory returns depend on the changes in the macroeconomic environment that influence labour demand [8]. Ultimately, creating productive job opportunities which support labour rights for all young Indonesians need to be the main objective in designing labour market regulations.

\section{Shortfalls in Labour Demand}

From macroeconomic perspective, youth employment outcomes are determined by the overall key indicators in the macroeconomic environment as well as GDP growth which influence changes in the labour demand [3]. A shortfall in demand affects a fall in labour demand in general and therefore affects youth population as well. Hence, adult employment and unemployment rates are frequently used by many researchers and analyst as a proxy of labour demand as they capture the overall impacts. There have also been an increasingly common views in labour economics in which youth are more sensitive than adult to fluctuations in aggregate demand. Many studies have explained the reasons behind vulnerability of youth to changes in aggregate demand such one by Bell and Blanchflower which argued that youth oftentimes have unsettled contracts and are not listed in employment protection [6]. Moreover, as youth account for the majority of job seekers, they get affected more during time periods of recession in which many companies stop their hiring process before implementing the termination procedure [27]. Hence, during crises, even when employees are still hired, companies tend to be more selective which leads young workers in an experience trap [28]. Consequently, youth unemployment is more vulnerable to changes in labour demand [2]. From a crosscountry data for the period of 1990-2010 outlines that the increase in growth rate as captured by GDP associated with employment rates among low and middle income countries, although only for a modest percentage [23]. However, in term of GDP volatility, it does not lead to rise in employment rates for which decision on investment would explain this result. Long-term investments in various key sectors in an economy tend to provide new productive employment opportunities. Limited percentage of investment will certainly influence job creation and therefore a shortfall in aggregate demand for youth as well. (A more detailed explanation on this issue of investment and other key macroeconomic indicators trends will be described in the next section). In addition, a recent study to test major determinants in poor employment outcomes in 
Indonesia using econometric analysis shows that subdued demand growth is more likely to have caused 'jobless' growth than the increase in labour cost which derived from minimum wage regulations [29]. While the structural and supply side factors in the labour market matter for youth employment outcomes to a varying extent, the explanation in this section has outlined that stimulating aggregate demand deserves further attention in order to create more employment opportunities for young people. To what extent are policy interventions used to increase the demand for youth labour market? The answer seems to be very little and that orthodox view that supply-side factors are more crucial to employment rates than demand-side approach cannot be proved by the relevant available evidence [12,30,31]

\section{E. Macroeconomic Developments Since the Asian Financial Crisis}

The figure 1 provides a snapshot of Indonesia's economic performance over the last two decades.

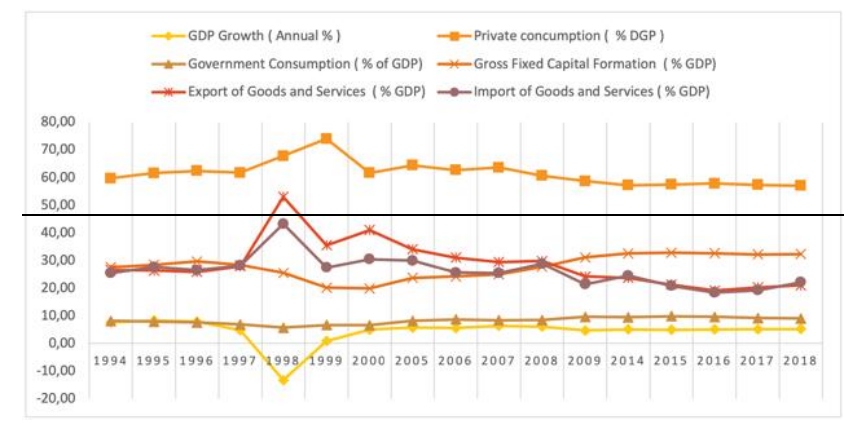

Source: World Development Indicator, World Bank

Fig. 1. Key macroeconomic indicators

In this section, I will also analyses how the economy has been responding toward the crisis in general, by looking at GDP growth, investment climate, external position of the country as well as its fiscal and monetary stance. First, I move to the 1997 AFC analysis. As we can see from figure 1 that the country suffered a severe financial crisis in the period 1997 1998, characterised by a sharp decline in GDP growth from nearly 8 percent in 1996 to almost minus 14 percent in 1998 . Investment, consumption and imports were the main drivers of economic growth before the economic crisis. However, there was a drastic reduction in the share of fixed investment which fell from nearly 30 percent in 1996 to 20 percent in 1999. Although there was indeed a slight recovery in 2005, sustaining its growth remained difficult as it only grew slowed and stayed at 32 percent in 2017 , just above the percentage of the precrisis number. Thus, the economy in the post-crisis period remained demand constrained until the recovery of growth since 2006. The evidence of this is found in the sharp decline of the share of exports in 1999 from nearly 53 percent in 1997, exports continued to decline until 2018 stood at 20 percent. This external position of the country indicates that a decrease in production of goods as a result of a sharp decline in exports leading to lower domestic demand. This instability of goods demand causes difficulties for firms to take part in the international markets as the country is losing its competitiveness which also means lower growth and a decline in employment opportunities.

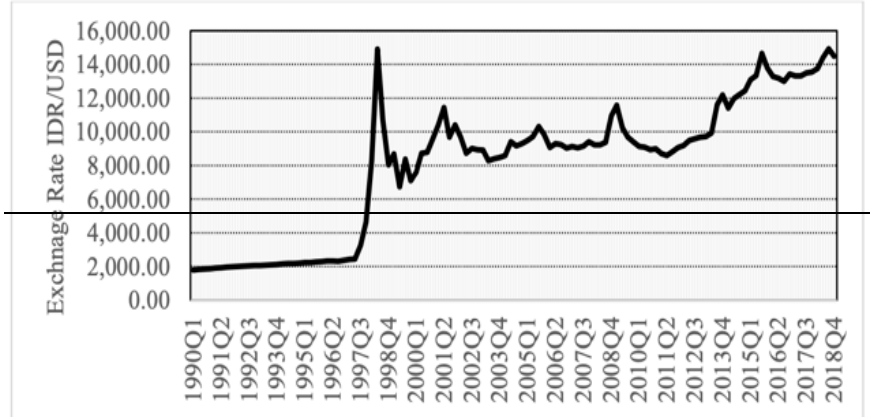

Source: Bank of Indonesia (BI)

Fig. 2. Indonesia exchange rate (IDR to USD) $1990-2018$

In term of exchange rate (figure 2), the 1997 AFC caused a significant devaluation of rupiah from 2,450 in 1997 to nearly 15,000 in 1998 which certainly had affected the overall Indonesian economy dramatically. Although it has decreased markedly 1999 but due to recent crisis it has rose again sharply until in 2018, the rupiah has the same number in exchange rate to that during the crisis. A prominent increase in debt repayments for loans denominated in foreign currencies have indeed rise demand for US dollar which caused even worse deterioration in the exchange rate. This-phenomenon caused difficulties for many companies in financing their vital working asset as the subsequent credit crisis generated contraction in loan which then force firms out of business and led to a substantial rise in the amount of non-performing loans. Furthermore, the exchange rate plays an important part in the economy diversification as it can affect the expected returns in investment. Empirical cross- country research have outlined that in order to incentivise companies in expanding their exports agenda, the exchange rate has to be in a stable and competitive rate to be able to allocate resources between the traded and non-traded sectors [23]. This will lead to a substantial rise in investment as well as economic growth which will positively generate not only diversification in other sector but also higher employment opportunities. Moreover, this exchange rate level also affects labour market outcomes for its influence on the intensity of labour production. In order to generate job creation for both young and adult workers may thus come from a stable exchange rate $[32,33]$.

\section{F. Private Sector's Role and Barriers to Job Creation: Evidence and Policy Implications}

It is commonly claimed that structural supply-side factors hold true to poor employment outcomes for young population and hence are two most crucial constraint to youth employment. This assumption, however, ignores the role of macroeconomic policies in affecting employment opportunities for youth. In the previous section, I have examined the impact 
of growth and other macroeconomic variables on youth labour market outcomes. The next step is now to analyses the role and barriers that private sectors confront while expanding their business operations. Ensuring the stability in macroeconomic policies, therefore, plays a critical role in generating jobs opportunities as they can reduce constraints faced by private sectors in job creation. Two major barriers highlighted by companies in developing countries as stated in the enterprise level surveys are access to finance and use of reliable supply of electricity. Labour regulations, on the other hand, account for only less than five percent of companies.
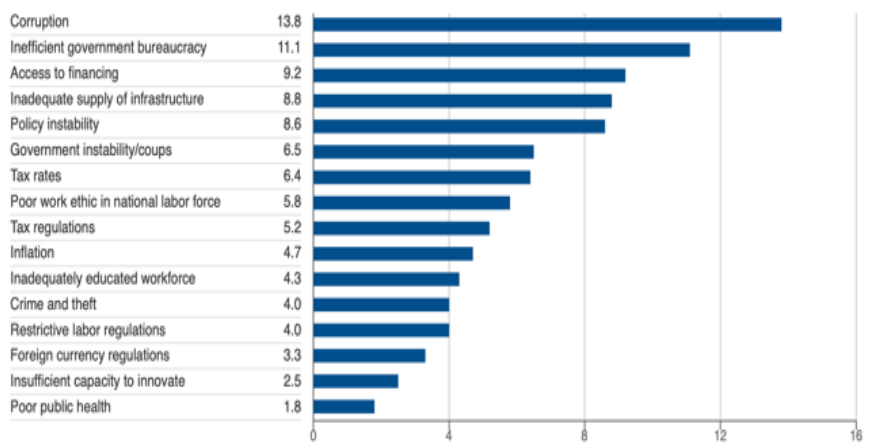

Source: World Economic Forum, Executive Opinion Survey 2017

Fig. 3. Most problematic factors for doing business in Indonesia.

When other relevant sources are utilised, a similar pattern have found. For example, a survey taken by the World Economic Forum in the Global Competitiveness Report which undertake in more than 100 countries including Indonesia, summarised that access to finance is one of the five major constraints in doing business (figure 3). In Indonesia insufficient lack of financing and inadequate infrastructure are ranked among the five most constraining factors in as much as 92 per cent and 88 per cent respectively. In opposite to what is frequently argued, an inadequately educated workforce is not listed as the crucial factor in business operations in two-third of the surveyed countries (World Economic Forum).

The results outlined above emphasized the need to effectively invest on both accesses to finance and infrastructure. This, in practice will need the relevant changes in the monetary and fiscal policies framework. Despite being a major concern of central banks and finance ministries, the World Economic Forum's Global Competitiveness Report shows that inflation, especially in low and middle-income countries, is not considered one of the top five constraints to growth for the private sector. This does not mean to ignore the role of inflation for the stability of macroeconomic policies but to suggest that employment stabilisation should be integrated in the objective of the central bank. This will need to include the real exchange rate and the allocation of investment in the policy design of macroeconomic variables [33]. These mixes of policies will generate more business operations through the rise in private investment and help improve the entrepreneurial skills of youth through an adequate government aid in finance. Additionally, a substantial rise of public investment in infrastructure would also be needed in order to minimise the barriers on private sector growth. Therefore, it is imperative to utilise capitals to help government close the gap in spending, particularly in infrastructure. Policy frameworks to improve infrastructure through financial inclusion are required to stimulate aggregate demand for labour which in turn lead to more work opportunities for young people.

\section{CONCLUSION}

Lack of productive employment opportunities for young people has become serious in the wake of both the 1997 Asian financial crisis and global financial crisis. This has become unpleasantly true in emerging economies, particularly Indonesia. The tragedy is that young people could suffer from the scarring effect as a result of poor employment prospects which left them underutilised as the economy is experiencing a demand shock in the labour market. Those who are at the lower end of skill are particularly prone to this scarring effect. Moreover, this phenomenon of high rate of youth unemployment generates negative externalities not only in the economic aspects but also psychology and social aspects resulting higher rates of poverty and inequality as well as higher incidence of crime, unhappiness and other mental health issues [6].

This research drew on such a dismal background to examine the prominent issues and provide new perspective on analysing the high pertinent rates of youth unemployment in Indonesia. The paper noted that there has been a growing debate in regard to the determinants of poor youth labour market outcomes in Indonesia which focus on a structural and supply-side approach stemming from skills mismatch issues and insufficient labour market flexibility. This supply-side argument, although dominant comes with various issues. In the cross-country evident, as youth unemployment rates are particularly sensitive to business cycle, higher skills will not automatically lead to higher employability. In fact, the data shows that in low and middle income countries, higher years of schooling associated with lower employment rates [23]. This is particularly true in the case of Indonesia, even after trying to close skills gap through prioritising vocational and higher education, evidence from recent official statistics of Indonesia showed that unemployment rate among secondary vocational school and university graduates are among the highest across all education levels even in a stable condition of economic of the country [1]. Hence, there has to be a comprehensive approach to skills policies as the relationship between schooling and employment opportunities is indeed insubstantial. The paper also argued that the view that labour market rigidity which includes wage push orthodoxy as one of the most crucial factors to generating youth employment is somewhat influential. However, this is not based on solid evidence. As the cross-country study shows that the appropriate policy intervention to labour market is not necessarily more or less regulation, but a relevant mix of policies that enable young workers to get sufficient benefits and productive jobs opportunities. This opens the way to 
propose that macroeconomic and demand-side approach may have the most prominent impact in generating job creation in the long run through the pattern of growth.

As the focus on youth unemployment debate in Indonesia has very much been on the structural and supply-side approach, this study offers a critical assessment of that orthodox view to unemployment and growth problem in Indonesia. Through the application of Post-Keynesian macroeconomic framework, it argues that a shortfall in aggregate demand restrains rapid production and job growth and that the economy of Indonesia best understood as a reflection of a demand-constrained environment which resulted in a nonoptimal operation. First, the paper begins by analysing the macroeconomic key indicators as well as fiscal and monetary stance of the country and the impacts they bring on youth labour market outcomes. It demonstrates that tight fiscal and monetary policies for long periods of time may have damaged the long-term economic potential leading to a low investment-low demand-low productivity circle. The country also needed to overcome its budget deficit issues and initiate public investment in human resource development, infrastructure and agricultural development. Those public investments generate an increase in government revenue as well as decline in social expenditure which in turn correct the budget deficits.

Further, the paper then move on to have identified that one of the most crucial factors to help youth population obtain a sound employment prospects is by examining the binding barriers of the private sectors in generating job creation. A survey taken by the World Economic Forum in the Global Competitiveness Report which undertake in more than 100 countries including Indonesia, summarised that instead of inflation rate and labour market regulations which oftentimes referred as the central concern to the private sectors, access to finance and infrastructure are actually cited as among most critical constraints in doing. Prioritising sufficient investment in infrastructure is therefore an important policy focus which backed up by econometric analysis using cross-country data that argued that lack of investment is positively associated with poor youth employment outcomes [23]. Thus, this study described that in order to change the curve of labour demand outwards leading to a more productive employment, a dynamic policy framework which generates productivity growth is needed. Macroeconomic policy with employment stabilisation as its goal would be needed to achieve this long-term development strategy, which may include taking moderate inflation rate in line with Indonesia's past inflation rate experience.

In sum, the current youth employment crisis cannot be neither avoided nor ignored. Otherwise, a long-run scarring effect will drag youth down in this uncertain political and social situation. The drivers of poor youth employment outcomes as well as the policy lessons and implications are all now well explained. While structural and supply-side approach stemming from skill mismatches and labour market legislations have indeed play a role, macroeconomic and demand-side perspectives affect more significantly. Decisive policy interventions and further research to overcome the current poor youth employment outcomes of Indonesia need to be emerged from that premise.

\section{REFERENCES}

[1] Statistics Indonesia (BPS), Youth Annual Report. Jakarta: Badan Pusat Statistik, 2019.

[2] M.T. Choudhry, E. Marelli, and M. Signorelli, "Financial crises and labour market performance," in International Atlantic Economic Conference, Prague, 2010, pp. 24-27.

[3] N. O'higgins, "The challenge of youth unemployment," Int. Soc. Secur. Rev., vol. 50, no. 4, pp. 63-93, 1997.

[4] E.R. Tiongson and J. Fares, Youth unemployment, labor market transitions, and scarring: evidence from Bosnia and Herzegovina, 200104. The World Bank, 2007.

[5] W. Arulampalam, P. Gregg, and M. Gregory, "Introduction: unemployment scarring," Econ. J., vol. 111, no. 475, pp. F577-F584, 2001

[6] D.N.F. Bell and D.G. Blanchflower, Youth unemployment: déjà vu? Stirling: University of Stirling, 2009

[7] M. Oey-Gardiner and P. Gardiner, Indonesia's Demographic Dividend or Window of Opportunity?, Social Science Commission of the Indonesian Academy of Sciences, Indonesia, 2013.

[8] A. Chowdhury and I. Islam, "A critique of the orthodox approach to Indonesia's growth and employment problems and post Keynesian alternatives,” Am. J. Econ. Sociol., vol. 70, no. 1, pp. 269-299, 2011

[9] G.W. Imbens and J.M. Wooldridge, "Recent developments in the econometrics of program evaluation," Journal of economic literature, vol. 47, pp. 5-86, 2009.

[10] D. Finegold and D. Soskice, "The failure of training in Britain: analysis and prescription," Oxford Rev. Econ. policy, vol. 4, no. 3, pp. 21-53, 1988.

[11] L. Nagib and N.F.N. Ngadi, "Challenges Of Unemployment In Indonesia: Trends, Issues And Policies,” J. Kependud. Indones., vol. 3, no. 2, pp. 1-28, 2008.

[12] V. Alatas and D. Newhouse, Indonesia jobs report: Towards better jobs and security for all. Washington, DC: Main Report, World Bank, 2010.

[13] J.M. Keynes, The general theory of interest, employment and money. London: Macmillan, 1936

[14] A.W. Phillips, "The relation between unemployment and the rate of change of money wage rates in the United Kingdom," economica, vol. 25 , pp. 283-299, 1958.

[15] J.R. Hicks, "Mr. Keynes and the" classics"; a suggested interpretation," Econometrica: journal of the Econometric Society, pp. 147-159, 1937.

[16] E.S. Phelps, "Money-wage dynamics and labor-market equilibrium," Journal of political economy, vol. 76, pp. 678-711, 1968.

[17] J. Tobin, "A general equilibrium approach to monetary theory," Journal of money, credit and banking, vol. 1, pp. 15-29, 1969.

[18] F.H.B. Terra, and F.F. Filho, "Reflections on the Keynes' metho," Revista Venezolana de Análisis de Coyuntura, vol. 24, pp. 85-101, 2018

[19] J.M. Keynes, The general theory of employment, interest, and money, reprint. London: Macmillan, 1973.

[20] D. Suryadarma, A. Suryahadi, and S. Sumarto, The measurement and trends of unemployment in Indonesia: The issue of discouraged workers. Available at SSRN 861464, 2005.

[21] I. Islam and S. Verick, From the Great Recession to Labour Market Recovery: Issues, Evidence and Policy Options. ILO, Geneva, and Palgrave Macmillan, Basingstoke, 2011.

[22] J. Anyon, "What "counts" as educational policy? Notes toward a new paradigm," Harvard Educational Review, vol. 75, pp. 65-88, 2005.

[23] M. Matsumoto, M. Hengge, and I. Islam, Tackling the youth employment crisis: A macroeconomic perspective. Geneva: ILO, 2012 
[24] M. Aleksynska and M. Schindler, Labor market regulations in low-, middle-, and high-income countries: A new panel database. Washington DC: IMF Working Paper WP/11/154, 2011.

[25] S. Dhanani, I. Islam, and A. Chowdhury, The Indonesian labour market: Changes and challenges (Vol. 79). Routledge, 2009.

[26] P. Honohan and L.A. Laeven, Systemic Financial Distress: Containment and Resolution. Cambridge (UK): Cambridge University Press, 2005.

[27] R. Shimer, "Reassessing the ins and outs of unemployment," Review of Economic Dynamics, vol. 15, pp. 127-148, 2012.

[28] F.E. Caroleo and F. Pastore, "The youth experience gap: explaining differences across EU countries," Quaderni del Dipartimento di Economia, Finanza e Statistica, vol. 41, 2007.
[29] A. Chowdhury, "Politics, Society and Financial Sector Reform in Bangladesh." International Journal of Social Economics, vol. 29, pp. 963-988, 2002.

[30] ILO, Global Employment Trends, International Labour Organization, Geneva, January, 2020.

[31] G. Betcherman, M. Godfrey, S. Puerto, F. Rother, and A. Stavreska, Global inventory of interventions to support young workers: Synthesis report. Washington, DC: World Bank, 2007.

[32] R. Frenkel and J. Ros, "Unemployment and the real exchange rate in Latin America,” World Dev., vol. 34, no. 4, pp. 631-646, 2006.

[33] G. Epstein and E. Yeldan, "Inflation targeting, employment creation and economic development: assessing the impacts and policy alternatives," International Review of Applied Economics, vol. 22, pp. 131-144, 2008. 